JARES, Vol. 1 No. 1 March, 2016; p-ISSN: 2502-826X; e-ISSN: 2503-1163

Copyrights@ Balitar Islamic University, Blitar, Indonesia; Http://jares.unisbablitar.ejournal.web.id

Citation: Andari, Bina. 2016. The Importance of Raw Materials Inventory Supervision

for Production Process. JARES, (2016), 1(1): 53-60.

\title{
THE IMPORTANCE OF THE RAW MATERIALS INVENTORY SUPERVISION FOR PRODUCTION PROCESS
}

\author{
Bina Andari \\ Balitar Islamic University
}

Email:

\begin{abstract}
This paper describes the importance of the raw materials Inventory supervision for production process. The concepts described in this paper was studied using the descriptive theoretical analysis. It is concluded that (1) Raw Materials Inventory control is highly needed by both small and big companies to take care of the production process stabilization; (2) The production process will find problems when there is no good control of the Inventory. This causes anstable production process effecting finnace of the companies. The long period of materials inventory causes campany loss. On the other hand, small amount of inventory will also cause the production processes stop. Such situation will also influence marketting and the supply to the consumers; (3) Unstable producation process will cause unstable product supply in the market, and (4) To ensure that the consumers' needs are continuously completed, control of the raw materials inventory needs to be done and maintained.
\end{abstract}

Keywords: Raw materials inventory, Supervision, Control, production process, stabilization.

\section{INTRODUCTION}

Companies producing goods for profit need to work for the good raw materials management as the raw materals are important factors in production process. To work for such management, they need costs which should be productively managed, too. The companies must be able to maintain the availability of raw materials inventory to ensure the good flow of production process with good quality, propper time, and effective cost. Too many inventories will harm the companies, since they have to invest capital and spend lots of epenses for the inventorying process. On the other hand, the small amount of inventorys will also harm the company, because the production process will suffer and the distirubtion is also disturbed.

The change of the inventory supply and distribution involve provision of the raw materials inventory, production process, product finalization, warehousing, and distribution. To provide raw materals inventory in propper time, sufficient ammount, and with effective cost, the companies have to manage supervision of the raw materials inventory. Supervision means examining and controlling activities to ensure that all works suit to the expectation and planning. Every supervision process is started with the determination of expected situation or condition. Therefore, supervision can also mean expected efforts, activities, or action process. Inventory supervision is an activity system to determine the extend and 
JARES, Vol. 1 No. 1 March, 2016; p-ISSN: 2502-826X; e-ISSN: 2503-1163

Copyrights@ Balitar Islamic University, Blitar, Indonesia; Http://jares.unisbablitar.ejournal.web.id

Citation: Andari, Bina. 2016. The Importance of Raw Materials Inventory Supervision

for Production Process. JARES, (2016), 1(1): 53-60.

composition of the inventorys to make the companies worked for the smootness of the raw materials provision, production, marketting and selling, and the budgetting expenses effectively and efficiently.

To understand the importance of the raw materials inventory supervision for production process, the writer gathered informations and theories to be analyzed. Further, the writer presents the concept of the raw materials Inventory supervision for production process descriptively under the sub headings of the focus.

\section{REVIEW OF LITERATURE}

\subsection{Definition of Inventory}

The company inventory is managed to ebsure the smoothness of the production process and to maintain the continuity of the company. The invoventory supervision involves recording the stocks, managing the stocks, and organizing the in and outflow of the stocks. This can ensure that all goods in the warehouse are sufficienly provided. Assauri (2004:169) says that inventory is an activa of the company materials in order to be sold in a normal period or the provision of materials which are still in process of production or even those raw marterials waiting for the production process. According to Riyanto (2001:9) the materials provision is the inventory or materials provision as the main elements of the working capital and as the activa which is in condition of processing and will eperience changes continuosly.

In general, the terms materials provision is used to show that those materials will be sold again or will be processed to be sold again. This is called an inventory which is always in condition of processing and experiencing changes of the materials forms. This is the working capital in terms of the raw materials, half work in process, and finished goods. This is managed by the aim of supporting and maintaining the smoootness of the company production process and to fulfill the market demands or consumers demands. Thus, it can be said that the inventory is a number of materials or goods provided for the production process, half work finished goods, and finished goods demanded by the market and the consumers.

\subsection{Definition of Supervision}

Assauri (2004:176) states that inventory supervision is an activity to determine the etend and composition of parts, raw materials, products provision so that the company can ensure the smoothness of the production and selling as well as epenses need effectively and efficiently. Meanwhile, Cahyono (2004:243) says that inventory supervision is one of the activities from the activities order related one among others in a production process according to the planned action that include time, ammount, quality, and quantity. Every company needs to provide inventory to ensure the continuation of the business with the amount of money to be invested. Therefore, the company must manage such activities optimumly (Assauri, 200:176).

The inventory supervision is to meet the following criteria:

1. The availaibility of the sufficient and ordered wharehouse with good placement and identification management,

2. The sentralization of the power and responsibility must be laid on one trusted person, especially the warehouse guard.

3. The recording system of the in and out flow of the materials and goods, 
JARES, Vol. 1 No. 1 March, 2016; p-ISSN: 2502-826X; e-ISSN: 2503-1163

Copyrights@Balitar Islamic University, Blitar, Indonesia; Http://jares.unisbablitar.ejournal.web.id

Citation: Andari, Bina. 2016. The Importance of Raw Materials Inventory Supervision

for Production Process. JARES, (2016), 1(1): 53-60.

4. The definit supervision of the materials and goods circulation

5. The accurate record of those being ordered, distributed, and served.

6. The physical checks of the materials and goods

7. Planning for exchanging materials and goods or refilling the materials and goods

8. Checking of the routine activity

So, to assure that all the materials and goods are used efficiently, the

company need to recod the materials and goods orderly and neatly. Handoko (2003:73) says that the effective supervision must meet the following characteristics: (1) Accurates, (2) Timely, (3) Objective and wholistic, (4) Strategic supervision point based, (5) Economically realistic, (6) Organiationally realistic, (7) Coordinated in the work flow, (8) Flexible, (9) Function as the operational guidance, and (10) Accepted by all members of the organiation. The supervision system must be able to persuade the autonomous feeling, responsibility, and sense of the achievement. The effective inventory supervision can control defects in the company.

\subsection{The Objectives and Function of the Inventory Supervision}

The objectives of the inventory system are (1) to maintain the availability of the raw materials stocks so that the company will sustain from the production process, (2) to maintain that the inventory is not too many or too few, (3) to avoid high cost due to small amounts of buying.

With the effective supervision the production process will be easily made effective. The stocks will remain effective and the cost will be managed effective. The main functions of the inventory supervision consists of (1) getting the raw materials effectively, (2) storing and mantaining the materials and goods orderly and propperly, (3) distributing raw materials and goods effectively causing for the effective production process and cost, (4) minimalizing investation in terms of materials or goods.

\subsection{The implementation of Inventory Supervision}

There are (three) main things to be considered in the implementation of the Inventory Supervision. These are (1) inventory supervision types, (2) steps of the inventory supervision, and (3) technique of the inventory supervision. There are three types of the inventory supervision, which are preliminary supervision, concurrent control supervision, and feedback supervision (Handoko, 2003:361). The supervision always starts with planning, objectives determination, standar determination, and goals determination.

The steps of the inventory supervison are determining the implementation standard (planning), determining the measurement of the inventory supervision implementation, measuring the implementation, doing gap analysis, and making correction (Handoko, 2003:363). Terry and Sarwoto say that the inventory supervision process contains the following main steps: determining measurement and standard guidelines, measuring or evaluating the completed works, comparing the standard with the implementation, and correcting for the deviation. This means that every work must be supervised and evaluated. Subagyo (2000:144) explains that the inventory techniques include reorder point system, periodic system, maximum and minimum inventory system, and visual system. Of these 5 (five) systems, the maximum and minimum inventory system is the flexible system. This is 
JARES, Vol. 1 No. 1 March, 2016; p-ISSN: 2502-826X; e-ISSN: 2503-1163

Copyrights@ Balitar Islamic University, Blitar, Indonesia; Http://jares.unisbablitar.ejournal.web.id

for Production Process. JARES, (2016), 1(1): 53-60.

worth using to count cost components. Prawirosentono (2000:73) says that the costs contain ordering and carrying costs. Ordering cost is that of being spent in every order. Carrying cost is that of being spent in every storage in wharehouse. Such costs must be made effective to make the order economically effective. The ordering costs are different from the carrying costs. To make the spending effective, the order must be in large numbers which will effect to the big carrying cost. Thus, orders must be economic. The economic order quantity can be counted by the following formula (Riyanto, 2001:79):

$\mathrm{EQQ}=\sqrt{2 \times R \times} S / \mathrm{px} 1$ where $\mathrm{R}$ is Numbers of units needed in a certain period (Eg. A year); $\mathrm{S}=$ ordering cost in each order; $\mathrm{P}=$ cost per unit; I: carrying cost of the wharehousing presented in percentation of the average value of inventory.

\subsection{Reorder Point}

In the raw materials provision, a company must count the size of the production process and relate to the readyh stocks to ensure that the compay is able to provide raw materials continuously to supply the demand of production process. Reorder point mus be determined and managed in such awa that the raw materials are available in lead time and not to effect in high cost of storage in the warehouses. Subagyo (2000:144) says that reorder point is rthe same as the numbers of goods needed in the lead time. Meanwhile, Assauri (2004:96) says that reorder point is the point of provision when the order must be done. The determination of the reorder point must consider lead time and avarage usage of the raw material factors comprising the consideration of the minimum and maximum stocks (Assauri, 2004: 195-196).

The minimum stock privision is the limit of the minimum provision of a material that must be provided (Assauri, 2004:195). Riyanto (2001:74) says that this is the so-called safety stocks to provide the materials on the basis of the demand. The safety stock is maintained to ensure the production process is working and this will also be influenced by the waiting and usage factors. The maximum provision must be made efficient and effective in supporting the demands. There must be careful counting of ordering and carrying costs. These are very important activities to avoid deffects. Prawirosentono (2000:60) says that the raw materials provision is the asset of the company which shall be monitored to ensure the smoothness and the continuation of production process. This must be done, because the continuation of the ready stocks will also effect to the contunuation of the production process (Gitosudarmo, 2000:143).

\subsection{Definition of the Production Process}

Production process is the way, method, and technique to create or to add the usage of materials or services by using existing resources (workforces, machine, materials, and money) (Assauri, 2004:75). Yamit (2004:123) says that production process is a transformation from raw materials or components or inputs to become other forms of products having high added value. Thus, production process is an activity to create or to add the usage or the added values by using the existing raw materials. 
JARES, Vol. 1 No. 1 March, 2016; p-ISSN: 2502-826X; e-ISSN: 2503-1163

Copyrights@ Balitar Islamic University, Blitar, Indonesia; Http://jares.unisbablitar.ejournal.web.id

Citation: Andari, Bina. 2016. The Importance of Raw Materials Inventory Supervision

for Production Process. JARES, (2016), 1(1): 53-60.

\subsection{Types of the production process}

There have been several types of production in a company. Assauri (2004:75) says that the types of production process can be differentiated into two types, which are continuous processes and intermitent or manufacturing processes. The continuous process is a production process on this basis of the product flow from an operation to other operations without the bulk at acertain point of the process. The company operate continuously to fulfill the market demands. Whenever the product stocks are needed in the market, the company continues working for the production process. Therefore, this will be in form of the mass production. The products are not just ordered by person or several people, but they are needed by many people in the market.

The sontinuous production process has the following characteristics:

(a) The products are standarized with small variation and in the form of mass production,

(b) The process involves product layout or departementation by products,

(c) The company use the so-called Special Purpose Machine,

(d) The individual operator influence is small and therefore, there should not needs of the high skills,

(e) Production process is not easy. This process can stop due to the damage or unreliable machine.

(f) Both machine and jobs shall be contolled.

(g) Raw materials provision is usually high and the continuous process can stop if the buying activities cannot be maintained.

(h) Materials are usually moved by using handling euipment atau flexible Varied path equipment handled by human beings such as froklift.

(i) In such process the company needs isle and work in process room.

\subsection{Relationship between Inventory Supervision and Production Process}

Inventory supervision is an activity to ensure that production activities are in line woth the business plan. When there is a contigency case, this case can be managed professionally. Prawirosentono (2000:60) says that "invoventory is a part of the company asset. Asset is a part of capital that must be controlled by management. This control is aimed at keeping for the stock of the inventory, so that needs of production can be covered." Gitosudarmo (2000:143) says that "Inventory of the basic materials shall be done, because the irregularities of the use of such materials can hinder the flow of production process, which can be the temporary stop of production process due to the lack of basic materials"

Raw materials inventory and provision has significant relation to the peroduction process. Raw materials inventory represents items purchashed or produced by the company to use in manufacturing a product. This are of course being the basic needs of the company for the process of production. Such materials can be in forms of direct and indirect products. Both products are very imporant for the production process. To ensure the inventory process including the initial purchase, requisition, finished goods, and costs of good solds are working well, inventory supervision is highly needed. Inventory supervision involves supervision and coordination of a perpetual inventory record of material, supplies and other general stock items. In doing such jobs, supervisors must be qualified and well trained. Supervisor must be 
JARES, Vol. 1 No. 1 March, 2016; p-ISSN: 2502-826X; e-ISSN: 2503-1163

Copyrights@ Balitar Islamic University, Blitar, Indonesia; Http://jares.unisbablitar.ejournal.web.id

Citation: Andari, Bina. 2016. The Importance of Raw Materials Inventory Supervision

for Production Process. JARES, (2016), 1(1): 53-60.

given certain accountability so that the supervision can be managed well. The company usually select the supervisors and test then using Level Supervision of Inventory (LSI).

The most important concepts of the relationship between Inventory Supervision and the Production process is that the production process will be in trouble, when the inventory supervision fails. This is due to the possibility that the irregularities and the unstable inventory can hinder the process of production. The most radical issue is about the production being stop due to the lack of the raw materials. The main tasks of the inventory supervisors are management, coordination, and control of inventory and systems of inventory management. Inventory Management includes the integrated management and control of assigned items of material. The work involves a number of processes such as: Requirements Determination, Material Distribution, Procurement Authorization and Funds Management (US Office of Personnel Management, 2010:2-3).

Material Coordination focuses on material support for particular projects, work operations, or programs including work such as: monitoring the status and effectiveness of material support, reviewing and analyzing operational reports and plans, work schedules, planned requirements, and other data, determining, initiating, and coordinating required actions by establishing and maintaining liaison with inventory managers, contractors or vendors, and planning organizations to schedule or advise as to timing of procurement, delivery, or emergency transportation, participating in or serving as chairperson at meetings or conferences concerning levels of material support, timing, locations, and related inventory requirements, and conducting special supply and demand studies and advising on procedures to be followed and reviewing financial data to determine reprogramming requirements (US Office of Personnel Management, 2010:4).

Inventory Control includes performing one or more of a wide variety of staff or administrative functions such as Initiating, developing, installing, or administering a control program, providing guidance on or conducting surveys of supply and inventory management functions, Analyzing, evaluating, revising, or developing new inventory management systems, developing long-range material support plans, directing, guiding, or reviewing material support programs, functions, and actions implemented by others; and/or performing quality assurance and review functions. (US Office of Personnel Management, 2010:5). Most companies recruits inevntory specialists to ensure that the inventory management and supervision work well.

\section{CONCLUSION}

The above description shows that Inventory supervision is very important. This will link the inventory provision and production process that can be a warranty to the continuation of the productions for effective demand and supply. It can be concluded that inventory supervision has significant influence to the production process in terms of:

1. Inventory supervision is held to ensure the success of the production plan and production process. When defects or contigency matters are found, with the inventory supervision such problems can be identified and resolved in time.

2. Inventory supervision is held to ensure that the stocks are available and therefore lacking and missing materials can be managed to make the production process run continuously. 
JARES, Vol. 1 No. 1 March, 2016; p-ISSN: 2502-826X; e-ISSN: 2503-1163

Copyrights@Balitar Islamic University, Blitar, Indonesia; Http://jares.unisbablitar.ejournal.web.id

Citation: Andari, Bina. 2016. The Importance of Raw Materials Inventory Supervision

for Production Process. JARES, (2016), 1(1): 53-60.

3. Inventory supervision can guarantee the customer satisfaction, because it can respond the suddent demand and requisition.

4. Inventory supervision is a part of the important wherehouse management to supports all production process and activities.

\section{REFERENCES}

Assaouri, S.(2004) Manajemen Produksi dan Operasi. Jakarta:LPUI

Cahyono (2004). Manajemen Produksi.Yogyakarta:IPWI

Gitosudarmo(2000).Manajemen Produksi.Yogyakarta:BPFE

Prawirosentono, S.(2000).Manajemen Operasi Analisis dan Studi Kasus. Jakarta:Bumi Aksara

Riyanto, B(2001).Dasar-dasar Pembelanjaan Perusahaan.Yogyakarta:BPFE

Sarwoto (1998).Dasar-Dasar Organisasi dan Manajemen.Jakarta:Penerbit Ghalia Indonesia Subagyo(2000).Manajemen Operasi.Yogyakarta:BPFE

U.S. Office of Personnel Management.(2010). Position Classification Flysheet for Inventory Management Series, GS-2010

Yamit(2004).Manajemen Persediaan.Solo:Ekonisia FR UII 
JARES, Vol. 1 No. 1 March, 2016; p-ISSN: 2502-826X; e-ISSN: 2503-1163

Copyrights@ Balitar Islamic University, Blitar, Indonesia; Http://jares.unisbablitar.ejournal.web.id

Citation: Andari, Bina. 2016. The Importance of Raw Materials Inventory Supervision

for Production Process. JARES, (2016), 1(1): 53-60. 